\title{
Elemental Composition of Particulate Matter in South-Asian Megacity (Faisalabad-Pakistan): Seasonal Behaviors, Source Apportionment and Health Risk Assessment
}

\author{
MUHAMMAD USMAN ALVI ${ }^{1,2,3}$, TARIQ MAHMUD ${ }^{2 *}$. MAGDALENA KISTLER ${ }^{3}$, ANNE KASPER-GIEBL ${ }^{3}$, \\ IMRAN SHAHID ${ }^{4}$, KHAN ALAM $^{5}$, FARRUKH CHISHTIE $^{6}$, LIVIU MITU $^{7 *}$ \\ ${ }^{1}$ Department of Chemistry, University of Okara, Okara, Pakistan \\ ${ }^{2}$ Institute of Chemistry, University of the Punjab, Lahore 54590, Pakistan \\ ${ }^{3}$ Institute for Chemical Technologies and Analytics, Vienna University of Technonolgy, Vienna, Austria \\ ${ }^{4}$ Institute of Space Technology, Islamabad, Pakistan \\ ${ }^{5}$ Department of Physics, University of Peshawar, Khyber Pakhtunkhwa, Pakistan \\ ${ }^{6}$ Spatial Informatics Group, Pleasonton, CA, USA \\ ${ }^{7}$ University of Pitesti, Department of Nature SciencesPitesti, 1 Targu din Vale Str., 110040, Romania
}

\begin{abstract}
The composition of atmospheric aerosols can help to identify pollution sources, particulate transportation and possible impacts on human health. In this study, seasonal variations and sources of elemental contents in PM 10 from Faisalabad area were investigated. In total 117 samples were collected on 24 hours basis from September 2015 to December 2016. The selected trace elements, viz., $\mathrm{Al}, \mathrm{Ba}, \mathrm{Ca}, \mathrm{Fe}, \mathrm{K}, \mathrm{Mg}, \mathrm{Mn}, \mathrm{Na}, \mathrm{P}, \mathrm{Pb}$, $S$ and $\mathrm{Zn}$ were measured by inductively coupled plasma optical emission spectrometry (ICP-OES). The average PM 10 concentration was found to be $744 \pm 392 \mu \mathrm{g} \mathrm{m} \mathrm{m}^{-3}$, exceeding the limits proposed by Pak-EPA (150 $\left.\mu \mathrm{g} \mathrm{m}^{-3}\right)$, US-EPA $\left(150 \mu \mathrm{g} \mathrm{m}^{-3}\right)$ and WHO $\left(50 \mu \mathrm{g} \mathrm{m}^{-3}\right)$. On average concentration basis, the elements were in the order of $\mathrm{Ca}>\mathrm{Al}>\mathrm{S}>\mathrm{Fe}>\mathrm{K}>\mathrm{Mg}>\mathrm{Zn}>\mathrm{Na}>\mathrm{Pb}>\mathrm{P}>\mathrm{Mn}>\mathrm{Ba}$. The elements apparently emitted from natural sources were dominant in spring and summer seasons, while those emitted from anthropogenic inputs were more prominent in winter and autumn seasons. A correlation analysis revealed that pairs of elements originated from common sources were suspended in the ambient air. The enrichment factors (EFs), principal component analysis (PCA) and cluster analysis (CA) indicated wind-blown dust, biomass burning, fossil fuel combustion and vehicular exhaust/non-exhaust emissions as major sources. A health risk caused by non-carcinogenic trace elements such as $\mathrm{Pb}, \mathrm{Zn}$ and $\mathrm{Mn}$ was also assessed according to the method specified by US-EPA.
\end{abstract}

Keywords: air quality, enrichment factors, trace elements, seasonal variations, multivariate analysis

Atmospheric aerosols are in the focus of scientific community due to their influence on deteriorating the overall air quality along with detrimental effects on human health [1,2]. In various studies serious human health implications such as asthma, bronchitis, cardiovascular diseases, lung cancer and premature deaths have been linked with long term exposures of urban aerosols [3,4]. Atmospheric aerosols are originated from both primary and secondary sources, having diverse size ranges and variety of constituents such as trace elements, carbonaceous contents, soluble ions, acids and mineral dust [5].

The factors such as prevailing meteorological conditions and anthropogenic contributions strongly influence the composition and rate of aerosol formation [6].

On the scale of air pollution, Asian countries have been placed at the top due to vast increase in industrialization and uncontrolled urbanization coupled with heavy traffic volumes [7]. Like other Asian countries, Pakistan is also facing the problem of air pollution and severity of the issue can be reflected from the fact that Karachi, Lahore, Peshawar and Rawalpindi cities of Pakistan have been placed among the top fifty most polluted cities of the world by WHO in 2016. The reports of Pak-EPA, 2006 and World Bank, 2006 have identified particulate matter concentrations, industrial emissions and enhanced traffic volumes as key factors involved in deteriorating the air quality of the region. Government of Pakistan has taken some initiatives such as drafting of Pakistan Clean Air Program (PCAP) and National Environmental Quality Standards (NEQS), however practically no change has been observed yet. Moreover, the above mentioned drafts are not only out-dated now and require a comprehensive revision but guidelines in them are still higher than the limits provided by WHO as given in (table 1S).

In recent times, enhanced elemental contents of atmospheric aerosols have been observed as a result of extensive anthropogenic burdens along with other secondary sources especially in the urban areas [8-10]. Many studies have associated the major human ailments to the elemental constituents present in the respirable fraction of particulate matter $[11,12]$. That's why the elemental particulates have been given due importance due to their potential to affect different strata of the environment [13]. Elemental particulates take entry into the atmosphere by natural as well as

*email:tariqm06@yahoo.co.uk;ktm7ro@yahoo.com 
anthropogenic means. Natural elemental contributions mainly comprised of emissions from disintegration of earthcrest and re-suspended surface soil or dust, while anthropogenic sources include emissions from vehicles, industry and burning of fossil fuels $[14,15]$. There has been observed a significant variation in the elemental distributions worldwide due to disparity in local anthropogenic activates and prevailing metrological conditions $[16,17]$. Due to adverse elemental effects on human health and environment, some limited and short-term studies based on trace elemental profiles have been carried out from diverse localities of Faisalabad (study area). The studies conducted from dense traffic areas, commercial centers and industrial zones reported very high concentrations of anthropogenic elements such as $\mathrm{Zn}, \mathrm{Ni}, \mathrm{Pb}, \mathrm{Cd}$, etc., while reports from rural and residential areas described elevated levels of crustal elements such as $\mathrm{Fe}, \mathrm{Mg}, \mathrm{Na}, \mathrm{Ca}, \mathrm{Ba}, \mathrm{Yb}, \mathrm{Cs}, \mathrm{La}, \mathrm{Rb}$, etc. Majority of the concentrations were crossing the limits fixed by Pak-EPA, US-EPA and WHO [18].

In order to overcome the health effects imposed by toxic elements and to control the elemental emissions into the atmosphere, it is high time to characterize elemental fraction of particulate matter along with their source apportionment. The main objective of this study is to measure $\mathrm{PM}_{10}$ concentrations during different seasons over a year in the urban area of Faisalabad along with study of composition, seasonal variations and source identification of elemental contents. The source profile of elemental constituents has been estimated by using enrichment factor analysis, principal component analysis and cluster analysis, which are considered as effective tools for identification and understanding of elemental distributions in the particulate matter [19, 20]. Moreover, health risk assessment of some selected non-carcinogenic elements has also been evaluated.

\section{Experimental part}

\section{Site description}

Faisalabad is located in the North-West part of the Indo-Gangetic Plain (Latitude $30^{\circ} 31.5^{\prime} \mathrm{N}$; Longitude $73^{\circ} 74^{\prime} \mathrm{E}$ ) at an elevation of $184 \mathrm{~m}$ above the sea level. Being the third largest metropolitan and major industrial center of the country, it is situated on the main road of China-Pak Economic Corridor (CPEC), leading from China border to the Gwadar harbor. The geographical location of Faisalabad and sampling place within the city has been shown in (Figure $1)$.

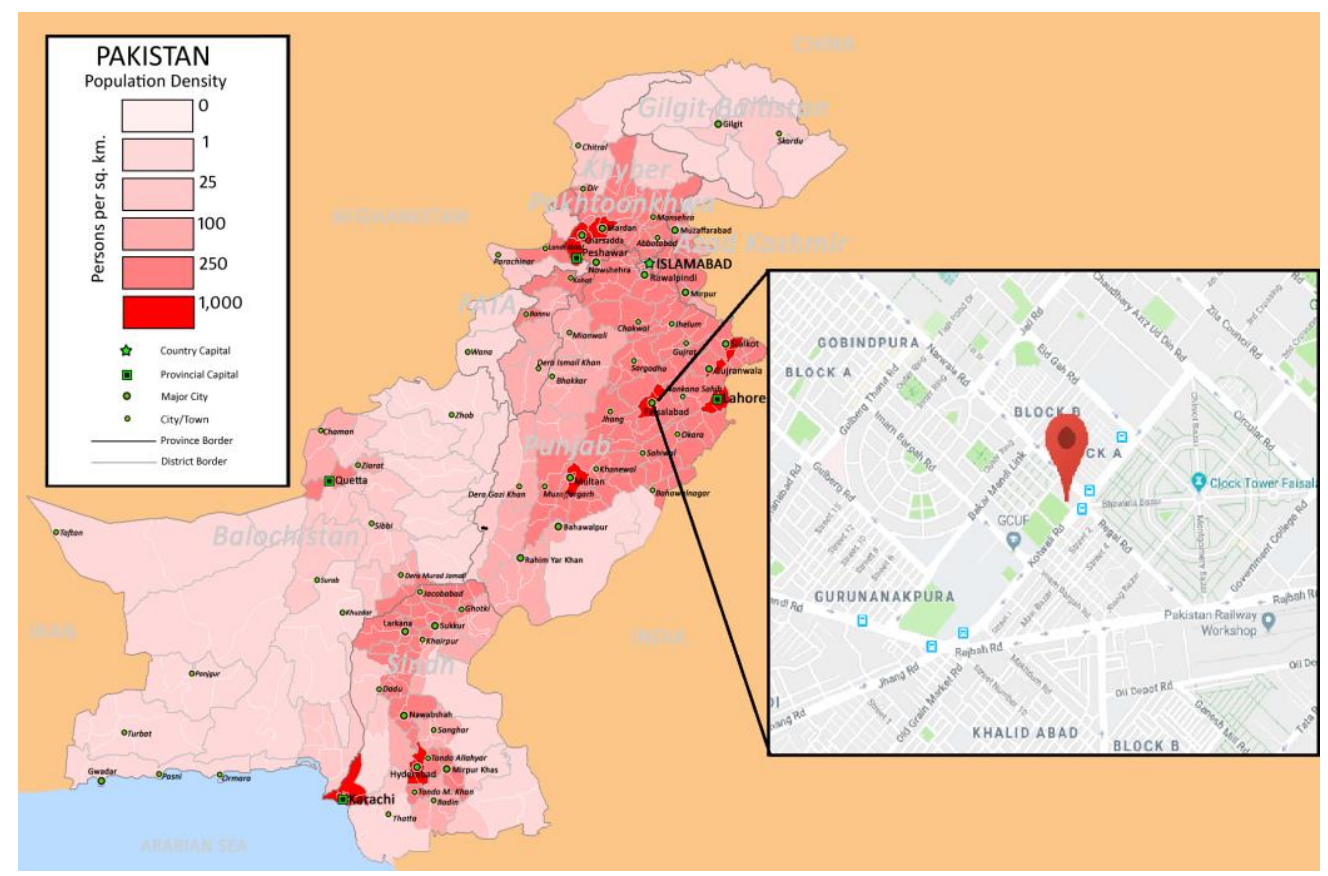

Fig. 1. Location of Faisalabad within the political map of Pakistan and sampling place within the city

The city lies in the subtropical zone with extreme climatic conditions. The city is prime industrial hub of the area having sugar, flour and seed oil mills. The products such as beverages, fertilizers, fabrics, hosiery, dyes, paper etc. are produced and processed here. The industries of electrical \& agricultural equipment and railway maintenance yards are also established in the city. However, just like other developing cities, the city air quality has been worsen by factors such as open solid waste combustion, inappropriate dumping of toxic industrial discharge, dense vehicular traffic and insufficient air emission monitoring and treatment. 


\section{Sampling}

In total 117 samples of $\mathrm{PM}_{10}$ size fraction were collected on $47 \mathrm{~mm}$ quartz fiber filters (Tissuquartz, Pall Life Sciences) from a site located on Kotwali road near the Clock Tower (city center). The sampling campaign continued from September 2015 to December 2016 with frequency of two samples per week and sampling duration of 24 hours. For this purpose, an automatic sampling device equipped with a $\mathrm{PM}_{10}$ pre-separation head (Leckel, Germany) having air intake capacity of $2.3 \mathrm{~m}^{3}$ per hour was used. Some field blanks were also collected in order to estimate any sampling artifacts. The collected samples were stored in the refrigerator by keeping them in parafilm sealed Petri dishes until further analysis.

\section{Chemical analysis}

$\mathrm{PM}_{10}$ mass was measured gravimetrically before the analysis. The selected elements were extracted from the filters by using a mixture of hydrochloric acid (37\%) and nitric acid (65\%). Simultaneous multi-elemental analysis (Al, Ba, $\mathrm{Ca}, \mathrm{Fe}, \mathrm{K}, \mathrm{Mg}, \mathrm{Mn}, \mathrm{Na}, \mathrm{P}, \mathrm{Pb}, \mathrm{S}$ and $\mathrm{Zn}$ ) was performed by using an iCAP 6500 series ICP-OES spectrometer (Thermo Scientific, USA). All chemicals used were procured from Merck (Darmstadt, Germany) and were of analytical grade. The custom assurance multi-element standards from Merck and Spex Certiprep (NJ, USA) were diluted in order to prepare standard solutions of the elements. In order to assess the accuracy and applicability of the method used, a certified reference material SRM $2709^{\circledR}$ from National Institute of Standards and Technology (NISTGaithersburg, USA) was investigated. The procedure of $\mathrm{PM}_{10}$ sample preparation, measurement of selected trace \& crustal elements and detail about uncertainties in the chemical analysis have been given by Mukhtar and Limbeck [21].

\section{Meteorology}

The meteorological parameters recorded during different seasons have been summarized in the (table $2 S$ ). The autumn season spans from mid of September to half past November. Heavy smog episode was witnessed during autumn 2016. The winter season starts from mid-November and lasts till halfway of February. The lowest temperature $\left(-1^{\circ} \mathrm{C}\right)$ along with dense fog spells were noticed during this season. The spring season starts after winter, having comparatively moderate temperature range $\left(23-25^{\circ} \mathrm{C}\right)$. The duration of summer season is from mid of April to the end of June. Dust storms, speedy winds and highest temperatures (up to $48^{\circ} \mathrm{C}$ ) were observed during this season. An average precipitation of $250 \mathrm{~mm}$ is observed annually and one half of it occurs in the monsoon. The duration of monsoon season is from July to mid of September.

In order to trace air mass origins at the study site during different seasons, the HYSPLIT backward trajectories were computed. In total one marine and two terrestrial air mass regimes were distinguished as illustrated in (Fig. 1S). The first air mass regime considered during autumn (September 2015) and summer (June 2016) was having air flow from the Arabian Sea and the areas of Thar \& Cholistan deserts. The second air mass regime was having air flow from Afghanistan and Iran along with locally derived air masses. It was simulated during winter (February 2016), spring (March 2016) and autumn (November 2016). The third air mass regime computed during August 2016 was from the eastern Indian side having lowest particulate concentrations due to the scavenging effects of eastern monsoon precipitation. The similar backward trajectory patterns were also simulated in other studies from the same region [22, 23].

\section{Results and discussions \\ $P M_{10}$ concentration}

The $\mathrm{PM}_{10}$ concentrations measured during different seasons have been summarized in (table $3 \mathrm{~S}$ ). The average $\mathrm{PM}_{10}$ concentration $\left(744 \pm 392 \mu \mathrm{g} \mathrm{m}^{-3}\right)$ measured in the present study was quite high in comparison to the reports from other Asian cities such as Islamabad $\left(280 \mu \mathrm{g} \mathrm{m}^{-3}\right)$, Quetta $\left(331 \mu \mathrm{g} \mathrm{m}^{-3}\right)$, Shanghai $\left(100 \mu \mathrm{g} \mathrm{m}^{-3}\right)$ and Hangzhou $(119 \mu \mathrm{g}$ $\left.\mathrm{m}^{-3}\right)$ [24-26].

Strong seasonal variations were observed during the sampling period and majority of the concentrations were out of the boundaries specified by Pak-EPA $\left(150 \mu \mathrm{g} \mathrm{m}^{-3}\right)$, US-EPA $\left(150 \mu \mathrm{g} \mathrm{m}^{-3}\right)$ and WHO $\left(50 \mu \mathrm{g} \mathrm{m}^{-3}\right)$. The highest concentrations were observed in the winter 2015-16 $\left(966 \pm 253 \mu \mathrm{g} \mathrm{m}^{-3}\right)$ and autumn $2016\left(1098 \pm 454 \mu \mathrm{g} \mathrm{m}^{-3}\right)$. Comparatively moderate concentrations were noted in autumn $2015\left(622 \pm 277 \mu \mathrm{g} \mathrm{m}^{-3}\right)$, spring $2016\left(612 \pm 338 \mu \mathrm{g} \mathrm{m}^{-3}\right)$ and summer $2016\left(757 \pm 301 \mu \mathrm{g} \mathrm{m}^{-3}\right)$, while lowest concentrations were observed in the monsoon $2016(283 \pm 76 \mu \mathrm{g}$ $\left.\mathrm{m}^{-3}\right)$. In autumn season, higher particulate concentrations were appeared due to massive burning of crop remnants so that fields can be cleared for next cultivation [27, 28]. Due to heavy smog episode in autumn 2016, about 1.7 times higher $\mathrm{PM}_{10}$ concentrations were recorded as compared to autumn 2015. In winter 2015-16, higher $\mathrm{PM}_{10}$ values were observed due to biomass combustion for heating on small house hold and commercial scales $[29,30]$. Moreover, low mixing height and stagnant air masses along with fog spells restrict the particulate dispersions and trigger the formation of secondary particulates [31-33]. In summer 2016 and spring 2016, major particulate contributions were from crustal and road dust re-suspensions which were favored by high temperatures, fast blowing winds and dust storms [34]. Lowest concentrations in monsoon were reasoned due to washout effects of rains [35, 20]. 


\section{Elemental concentrations}

The summary of the average elemental concentrations, standard deviations and ranges have been provided in the (table 3S). The highest concentrations were appeared in the summer 2016 followed by autumn 2016 and winter 201516, while lowest levels were observed in the monsoon 2016. Among the major elemental constituents, the highest concentration was observed for $\mathrm{Ca}$ for all the seasons except autumn 2016 as shown in (Fig. 2). The average concentration of $\mathrm{Ca}$ was found to be $33.59 \pm 18.67 \mu \mathrm{g} \mathrm{m} \mathrm{m}^{-3}$, with the highest value in summer 2016 and lowest during monsoon 2016. The average concentrations of $\mathrm{Al}, \mathrm{Fe}$ and $\mathrm{Mg}$ were found to be $22.13 \pm 10.50 \mu \mathrm{g} \mathrm{m}^{-3}, 18.77 \pm 11.47 \mu \mathrm{g}$ $\mathrm{m}^{-3}$ and $10.42 \pm 7.06 \mu \mathrm{g} \mathrm{m}^{-3}$ respectively. The seasonal trend of these elements was same i.e. the highest levels during summer 2016 and lowest levels during monsoon 2016. On the other hand, the average concentration of S and $\mathrm{K}$ was found to be $20.56 \pm 21.04 \mu \mathrm{g} \mathrm{m}^{-3}$ and $12.38 \pm 8.07 \mu \mathrm{g} \mathrm{m}^{-3}$ respectively; having highest values during autumn 2016 and lowest during monsoon 2016. In terms of \%age contribution towards total elemental contents, the highest contributions of $\mathrm{Ca}, \mathrm{Fe}$ and $\mathrm{Mg}$ were observed during summer 2016 (33, 19 and 11\%) and lowest during autumn 2016 $(18,9$ and 5\%). The elements such as S and $\mathrm{K}$ adopted completely opposite trend i.e. highest contributions during autumn 2016 (26 and 13\%) and lowest during summer 2016 (6 and 4\%). Al contributed moderately in all seasons except monsoon 2016, in which slightly high contribution of $23 \%$ was noticed.

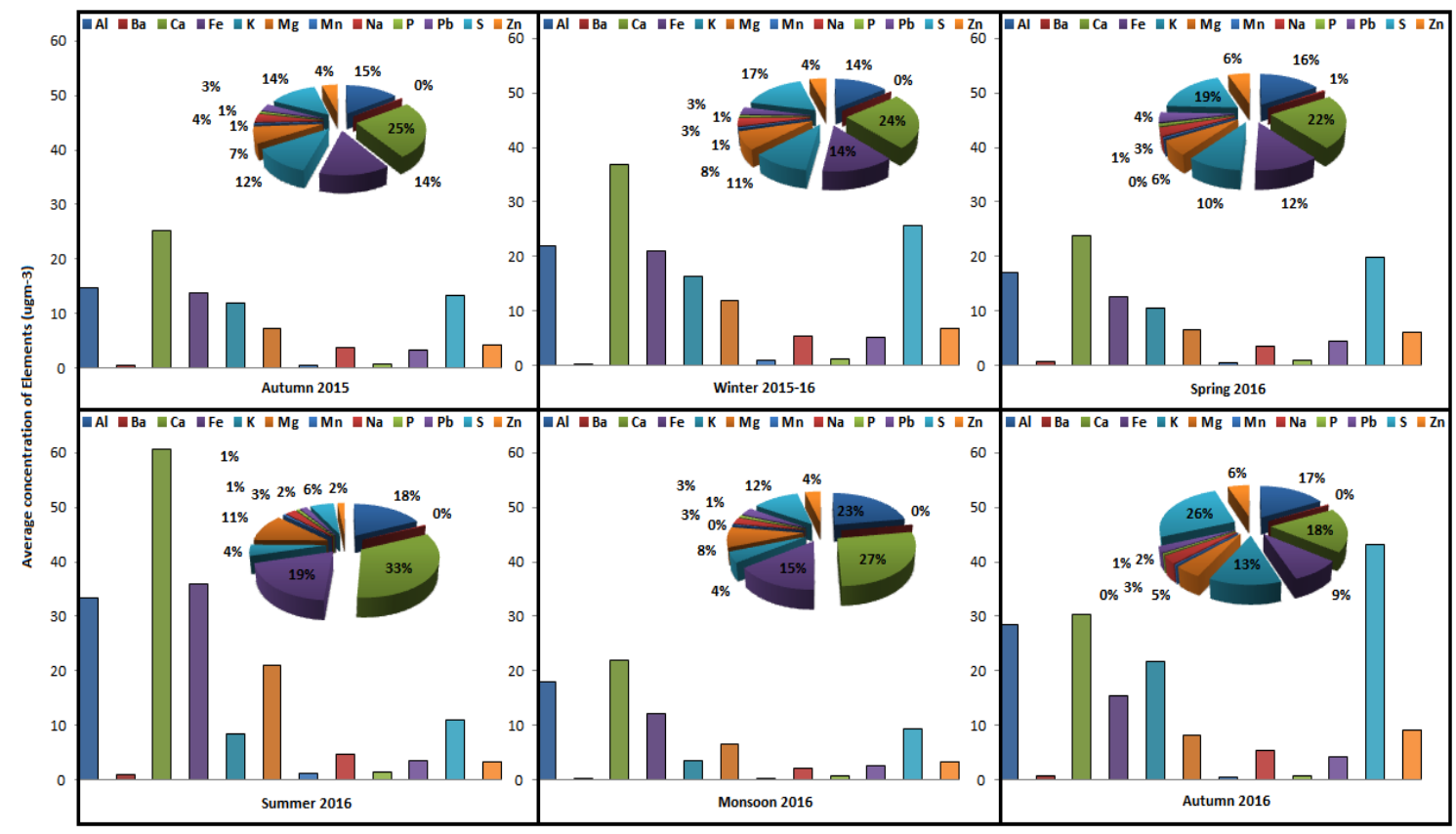

Fig. 2. The average concentrations of elements along with their percentages measured during different seasons

Among the minor elemental constituents, the highest concentration was observed for $\mathrm{Zn}$ for all the seasons except summer 2016. The average concentrations of $\mathrm{Zn}$ and $\mathrm{Na}$ were found to be $5.54 \pm 5.25 \mu \mathrm{g} \mathrm{m}^{-3}$ and $4.23 \pm 1.94 \mu \mathrm{g} \mathrm{m}^{-}$ ${ }^{3}$ respectively, with the highest levels during autumn 2016 and lowest during monsoon 2016. The average concentration of $\mathrm{Pb}$ was found to be $3.93 \pm 2.22 \mu \mathrm{g} \mathrm{m}{ }^{-3}$, with the highest level during winter 2015-16 and lowest during monsoon 2016. On the other hand, the average concentrations of P, Mn and Ba were found to be $0.96 \pm 0.44 \mu \mathrm{g}$ $\mathrm{m}^{-3}, 0.66 \pm 0.47 \mu \mathrm{g} \mathrm{m}^{-3}$ and $0.51 \pm 0.88 \mu \mathrm{g} \mathrm{m}^{-3}$, having highest values in summer 2016 and lowest during monsoon 2016. In terms of $\%$ contribution, the highest contribution of $6 \%$ was observed for $\mathrm{Zn}$ during autumn 2016 and spring 2016, while lowest during summer $2016(2 \%)$. A constant contribution was observed for $\mathrm{Na}(3 \%), \mathrm{Pb}(2 \%)$ and $\mathrm{P}$ (1\%) for all the seasons. Among all the elements, the lowest contribution of $\leq 1 \%$ was observed for $\mathrm{Mn}$ and Ba for all the seasons.

The average concentration of $\mathrm{Pb}\left(3.93 \mu \mathrm{g} \mathrm{m}^{-3}\right)$ in the present study was found to be higher than the specifications of Pak-EPA $\left(1.0 \mu \mathrm{g} \mathrm{m}^{-3}\right)$, WHO $\left(0.5 \mu \mathrm{g} \mathrm{m}^{-3}\right)$ and US-EPA $\left(1.5 \mu \mathrm{g} \mathrm{m}^{-3}\right)$. Similarly, the average concentration of Mn $(0.66$ $\left.\mu \mathrm{g} \mathrm{m}^{-3}\right)$ was out of the safety limits of WHO $\left(0.15 \mu \mathrm{g} \mathrm{m}^{-3}\right)$ and US-EPA $\left(0.5 \mu \mathrm{g} \mathrm{m}^{-3}\right)$ [13]. For comparison, a summary of some studies on the elemental concentrations in the particulate matter from regional and international locations have been given in the (table 1).

The elemental concentrations emerged in the present study were found to be higher than the nationwide inventories from (Faisalabad [36], Lahore [37], Islamabad [38]). The concentrations were also found higher than the reports from international cities such as (Dhaka [39], Chengdu [40], Istanbul [41], Milan [42]). 
Table 1

SUMMARY OF THE ELEMENTAL CONCENTRATIONS IN PARTICULATE

MATTER FROM NATION WIDE AND INTERNATIONAL STUDIES

\begin{tabular}{|c|c|c|c|c|c|c|c|c|c|c|c|c|c|c|c|}
\hline Area and Place & Study Period & PM & Al & $\mathrm{Ba}$ & $\mathrm{Ca}$ & $\mathrm{Fe}$ & $\mathrm{K}$ & $\mathrm{Mg}$ & $\mathrm{Mn}$ & $\mathrm{Na}$ & $\mathrm{P}$ & $\mathrm{Pb}$ & $\mathrm{S}$ & $\mathrm{Zn}$ & Reference \\
\hline $\begin{array}{l}\text { Faisalabad, } \\
\text { Pakistan }\end{array}$ & Dec 2002 & $435^{\circ}$ & 58 & 1.0 & 41.7 & 40 & 31 & 54 & 0.68 & 49 & - & 2.6 & - & 1.0 & $\begin{array}{l}\text { (Waheed et al. } \\
2005 \text { ) }\end{array}$ \\
\hline $\begin{array}{c}\text { Faisalabad, } \\
\text { Pakistan }\end{array}$ & $\begin{array}{c}\text { May 2012-Apr } \\
2013\end{array}$ & $645^{:}$ & - & - & 10.9 & 9.9 & 10.1 & 4.8 & - & 8.0 & - & 3.3 & - & 9.1 & $\begin{array}{l}\text { (Javed et al., } \\
2016 \text { ) }\end{array}$ \\
\hline $\begin{array}{c}\text { Faisalabad, } \\
\text { Pakistan }\end{array}$ & $\begin{array}{c}\operatorname{Jan} 1992-\text { Dec } \\
1992\end{array}$ & $550^{\circ}$ & - & $11.1^{\mathrm{d}}$ & - & $14.5^{d}$ & - & - & - & $244^{d}$ & - & $549^{d}$ & - & $16.1^{d}$ & $\begin{array}{c}\text { (Qadir and Zaidi, } \\
2006)\end{array}$ \\
\hline Lahore, Pakistan & $\operatorname{Mar} 2010$ & $406^{2}$ & 12.08 & 0.111 & 18.35 & 10.25 & - & 5.69 & 0.29 & - & 0.41 & 0.92 & 5.60 & 3.02 & $\begin{array}{c}\text { (Alam et al. } \\
\text { 2014) }\end{array}$ \\
\hline Lahore, Pakistan & $\begin{array}{c}\text { Mar 2010- Apr } \\
2010\end{array}$ & $382^{\circ}$ & 9.52 & $100^{d}$ & 20.67 & 8.24 & 2.87 & 3.23 & $205^{d}$ & 5.53 & $414^{d}$ & 1.10 & 5.42 & 1.64 & $\begin{array}{c}\text { (Alam et al. } \\
\text { 2011) }\end{array}$ \\
\hline Lahore, Pakistan & $\begin{array}{c}\text { Nov } 2005-\mathrm{Jan} \\
2006\end{array}$ & $190^{\circ}$ & $838^{d}$ & $11.1^{\mathrm{a}}$ & $795^{d}$ & $2815^{\mathrm{d}}$ & $1711^{d}$ & $393^{d}$ & $129^{d}$ & $346^{d}$ & - & $850^{d}$ & - & $3828^{d}$ & $\begin{array}{c}\text { (Raja et al., } \\
2010)\end{array}$ \\
\hline Lahore, Pakistan & $\begin{array}{c}\mathrm{Jan}_{2007-} \mathrm{Jan}_{2008} \\
\end{array}$ & $336^{2}$ & 8.4 & 0.12 & 9.1 & 8.2 & 5.6 & 2.1 & 0.3 & 1.9 & 0.3 & 4.4 & 6.4 & 11 & $\begin{array}{c}\text { (Schneidemesser } \\
\text { et al., 2010) }\end{array}$ \\
\hline $\begin{array}{l}\text { Rawalpindi, } \\
\text { Pakistan }\end{array}$ & $\begin{array}{c}\text { Mar 2010- Apr } \\
2010\end{array}$ & $715^{\circ}$ & 10.77 & $152^{d}$ & 74.96 & 15.03 & 7.44 & 5.98 & $375^{d}$ & 13.25 & $958^{d}$ & 3.90 & 4.41 & 5.03 & $\begin{array}{c}\text { (Alam et al. } \\
\text { 2011) }\end{array}$ \\
\hline $\begin{array}{l}\text { Islamabad, } \\
\text { Pakistan }\end{array}$ & $\begin{array}{c}\text { Jun 2005- May } \\
2006\end{array}$ & $198^{*}$ & - & - & $7611^{d}$ & $3705^{\mathrm{d}}$ & $2582^{d}$ & $1360^{d}$ & $81^{d}$ & $3815^{d}$ & - & $118^{d}$ & - & $2032^{d}$ & $\begin{array}{c}\text { (Shah and } \\
\text { Shaheen, 2010) }\end{array}$ \\
\hline $\begin{array}{c}\text { Islamabad, } \\
\text { Pakistan }\end{array}$ & $\begin{array}{c}\text { Apr 2010- Sep } \\
2010\end{array}$ & $143^{\circ}$ & - & - & 12757 & $3270^{d}$ & - & $797^{d}$ & $52.3^{a}$ & - & - & $93.8^{a}$ & - & $33.5^{\mathrm{a}}$ & $\begin{array}{c}\text { (Ahmed } e t a l . \\
2014)\end{array}$ \\
\hline $\begin{array}{l}\text { Islamabad, } \\
\text { Pakistan }\end{array}$ & $\begin{array}{c}\text { Nov 2002- Apr } \\
2003\end{array}$ & - & - & - & - & 0.667 & 0.778 & - & 0.056 & 2.384 & - & 0.163 & - & 0.567 & $\begin{array}{c}\text { (Shah et al. } \\
2006)\end{array}$ \\
\hline $\begin{array}{l}\text { Islamabad, } \\
\text { Pakistan }\end{array}$ & $\begin{array}{c}\text { Sep 2003- Mar } \\
2004\end{array}$ & $19^{2}$ & - & - & - & 1.761 & 0.488 & - & 0.055 & 1.661 & - & 0.128 & - & 1.021 & $\begin{array}{c}\text { (Shah and } \\
\text { Shaheen, 2007) }\end{array}$ \\
\hline Peshawar, Pakistan & Apr 2011 & $480^{2}$ & 7.59 & 0.06 & 34.6 & 8.63 & 2.57 & 4.05 & 0.19 & 5.28 & 0.36 & 2.20 & 2.63 & 1.42 & $\begin{array}{c}\text { (Alam et al. } \\
2015)\end{array}$ \\
\hline Peshawar, Pakistan & $\begin{array}{c}\text { Mar 2010- Apr } \\
2010\end{array}$ & $800^{\circ}$ & 7.38 & $48^{d}$ & 34.57 & 8.56 & 2.68 & 4.04 & $199^{d}$ & 5.31 & $365^{\mathrm{d}}$ & 4.10 & 2.65 & 1.45 & $\begin{array}{c}\text { (Alam et al. } \\
\text { 2011) }\end{array}$ \\
\hline Karachi, Pakistan & $\begin{array}{r}\operatorname{Tan} 2006-\quad \operatorname{Jan} \\
2008\end{array}$ & $83^{b}$ & 40.13 & 0.348 & - & 3.175 & 26.90 & 0.414 & 0.038 & 412.0 & - & 0.529 & - & 1.117 & $\begin{array}{c}\text { (Mansha ot al. } \\
\text { 2012) }\end{array}$ \\
\hline Karachi, Pakistan & $\begin{array}{c}\text { Mar 2010- Apr } \\
2010\end{array}$ & $783^{\circ}$ & 19.92 & $180^{d}$ & 74.39 & 16.87 & 8.57 & 7.30 & $471^{d}$ & 17.84 & $1557^{\mathrm{d}}$ & 4.20 & 9.05 & 2.83 & $\begin{array}{c}\text { (Alam et al. } \\
2011)\end{array}$ \\
\hline West Bengal, India & $\begin{array}{c}\text { Apr } 2014 \text { Jun } \\
2014\end{array}$ & $308^{2}$ & - & - & 1.45 & - & 0.89 & - & 0.06 & 4.39 & - & - & - & 0.23 & $\begin{array}{c}\text { (Ghosh et al. } \\
2018 \text { ) }\end{array}$ \\
\hline $\begin{array}{l}\text { Brahmaputra, } \\
\text { India }\end{array}$ & $\begin{array}{c}\text { Dec 2010- Oct } \\
2014\end{array}$ & $52^{2}$ & 4.32 & - & 0.59 & 1.42 & 1.22 & 0.08 & 0.03 & 1.76 & - & 0.06 & - & - & $\begin{array}{c}\text { (Bhuyan ot al., } \\
\text { 2018) }\end{array}$ \\
\hline $\begin{array}{c}\text { Dhaka, } \\
\text { Bangladesh }\end{array}$ & $\begin{array}{c}\text { Mar 2001- Apr } \\
2001\end{array}$ & - & - & - & - & 24.8 & - & 0.41 & - & - & - & $279^{d}$ & - & $801^{d}$ & $\begin{array}{c}\text { (Salam et al., } \\
\text { 2003) }\end{array}$ \\
\hline Chengdu, China & $\begin{array}{c}\text { Nov 2014- Oct } \\
2015 \\
\end{array}$ & $173^{2}$ & - & $103.0^{d}$ & - & 3.18 & - & - & $112.5^{\mathrm{d}}$ & - & - & $85.8^{d}$ & - & $467^{d}$ & $\begin{array}{c}\text { (Cheng ot al. } \\
2018)\end{array}$ \\
\hline Tianjin, China & 2015 & $186^{2}$ & $6418^{d}$ & $75.24^{d}$ & $5560^{d}$ & $4529^{d}$ & $1377^{d}$ & $2037^{d}$ & $59.2^{d}$ & $974^{d}$ & - & $35.7^{\mathrm{d}}$ & - & $159^{d}$ & $\begin{array}{c}\text { (Zhang et al. } \\
2018)\end{array}$ \\
\hline Hangzhou, China & $\begin{array}{c}\text { Sep 2001- Aug } \\
2002\end{array}$ & $119^{2}$ & 2.73 & 0.48 & 4.17 & 2.19 & 4.16 & 0.50 & 0.13 & 1.15 & 0.51 & 0.37 & 5.74 & 0.55 & (Cao et al., 2009) \\
\hline $\begin{array}{c}\text { Klang Valley, } \\
\text { Malaysia }\end{array}$ & Dec 2014 & $207^{2}$ & - & $729^{d}$ & - & $629^{d}$ & - & - & $19.8^{a}$ & - & - & $24.2^{d}$ & - & $54.6^{a}$ & $\begin{array}{c}\text { (Elhadi ot al. } \\
2018)\end{array}$ \\
\hline Ulgan, Korea & $\begin{array}{c}\text { Apr 2008- Aug } \\
2008\end{array}$ & $50^{2}$ & $1475^{\mathrm{d}}$ & - & $2057^{d}$ & $382.9^{d}$ & $465^{d}$ & $476^{d}$ & $6.3^{\mathrm{d}}$ & $1191^{d}$ & - & $49.5^{d}$ & - & $261^{d}$ & $\begin{array}{c}\text { (Elhadi et al. } \\
\text { 2018) }\end{array}$ \\
\hline Duzce, Turkey & $\begin{array}{c}\text { Oct 2015- Mar } \\
2015\end{array}$ & $86^{2}$ & 5.3 & 21.4 & - & 2.5 & - & - & 29 & - & - & 21.1 & - & 115.3 & $\begin{array}{c}\text { (Bozkurt et al., } \\
\text { 2018) }\end{array}$ \\
\hline Istanbul, Turkey & $\begin{array}{c}\text { Nov } 2007-\text { Jun } \\
2009\end{array}$ & $150^{2}$ & 0.74 & - & 2.84 & 0.70 & - & - & 0.02 & - & - & 0.07 & - & 0.24 & $\begin{array}{c}\text { (Theodosi et al. } \\
2010)\end{array}$ \\
\hline Milan, Italy & $\begin{array}{c}\operatorname{Jan} 2003-\mathrm{Feb} \\
2003\end{array}$ & $81^{2}$ & $840^{d}$ & - & $1880^{d}$ & $1830^{d}$ & $660^{d}$ & - & $45^{a}$ & - & - & $71^{d}$ & $2360^{d}$ & $180^{d}$ & $\begin{array}{c}\text { (Vecchi ot al., } \\
2007)\end{array}$ \\
\hline
\end{tabular}

\section{Correlation analysis}

In order to disclose a preliminary linkage between elements and their possible sources, a correlation analysis of elements has been given in the (table 2). In the present study, Al was significantly correlated with $\mathrm{Ca}(\mathrm{r}=0.78), \mathrm{Fe}(\mathrm{r}$ $=0.78), \mathrm{Mg}(\mathrm{r}=0.77), \mathrm{Mn}(\mathrm{r}=0.62)$ and $\mathrm{Na}(\mathrm{r}=0.61)$. Similarly Ca was strongly correlated with $\mathrm{Fe}(\mathrm{r}=0.98), \mathrm{Mg}(\mathrm{r}$ $=0.98), \mathrm{Mn}(\mathrm{r}=0.83), \mathrm{P}(\mathrm{r}=0.52)$ and $\mathrm{Na}(\mathrm{r}=0.50)$. Mg was significantly correlated with $\mathrm{Mn}(\mathrm{r}=0.80)$, while $\mathrm{Mn}$ was strongly correlated with $\mathrm{Na}(\mathrm{r}=0.64)$ and $\mathrm{P}(\mathrm{r}=0.60)$. In the literature, airborne soil [37] and fugitive dust [43] has been reasoned for the emission of these elements. Fe was correlated with $\mathrm{Mg}(\mathrm{r}=0.99), \mathrm{Mn}(\mathrm{r}=0.84)$ and $\mathrm{P}(\mathrm{r}=$ 0.53). These elements have been regarded as markers of construction activities [40] and rubber \& steel industries [37].

$\mathrm{K}$ was correlated with $\mathrm{Na}(\mathrm{r}=0.78), \mathrm{S}(\mathrm{r}=0.73)$ and $\mathrm{Zn}(\mathrm{r}=0.54)$. Na was significantly correlated with $\mathrm{P}(\mathrm{r}=$ $0.80)$ and $\mathrm{S}(\mathrm{r}=0.50)$, while $\mathrm{S}$ was significantly correlated with $\mathrm{Zn}(\mathrm{r}=0.56)$. Anthropogenic contributions such as biomass burning, industrial and vehicular exhaust/non exhaust emissions were assumed for these elements [13, 43]. 
Table 2

CORRELATION COEFFICIENT MATRIX OF ELEMENTS IN PM 10

\begin{tabular}{|c|c|c|c|c|c|c|c|c|c|c|c|c|}
\hline Variable & $\mathrm{Al}$ & $\mathrm{Ba}$ & $\mathrm{Ca}$ & $\mathrm{Fe}$ & $\mathrm{K}$ & $\mathrm{Mg}$ & $\mathrm{Mn}$ & $\mathrm{Na}$ & $\mathrm{P}$ & $\mathrm{Pb}$ & $\mathrm{S}$ & $\mathrm{Zn}$ \\
\hline $\mathrm{Al}$ & 1 & & & & & & & & & & & \\
\hline $\mathrm{Ba}$ & $.276^{* *}$ & 1 & & & & & & & & & & \\
\hline $\mathrm{Ca}$ & $.786^{* *}$ & $.250^{* *}$ & 1 & & & & & & & & & \\
\hline $\mathrm{Fe}$ & $.782^{* *}$ & $.267^{* *}$ & $.982^{* *}$ & 1 & & & & & & & & \\
\hline $\mathrm{K}$ & $.341^{* *}$ & .053 & .048 & .020 & 1 & & & & & & & \\
\hline $\mathrm{Mg}$ & $.779^{* *}$ & $.263^{* *}$ & $.980^{* *}$ & $.993^{* *}$ & -.014 & 1 & & & & & & \\
\hline $\mathrm{Mn}$ & $.624^{* *}$ & $.218^{*}$ & $.832^{* *}$ & $.844^{* *}$ & $.263^{* *}$ & $.805^{* *}$ & 1 & & & & & \\
\hline $\mathrm{Na}$ & $.610^{* *}$ & .163 & $.509^{* *}$ & $.483^{* *}$ & $.783^{* *}$ & $.460^{* *}$ & $.642^{* *}$ & 1 & & & & \\
\hline $\mathrm{P}$ & $.431^{* *}$ & .063 & $.520^{* *}$ & $.530^{* *}$ & $.282^{* *}$ & $.489^{* *}$ & $.609^{* *}$ & $.532^{* *}$ & 1 & & & \\
\hline $\mathrm{Pb}$ & -.017 & .009 & -.030 & .009 & $.256^{* *}$ & -.030 & $.228^{*}$ & $.240^{* *}$ & $.269^{* *}$ & 1 & & \\
\hline $\mathrm{S}$ & $.334^{* *}$ & -.016 & -.142 & -.126 & $.733^{* *}$ & -.159 & .039 & $.501^{* *}$ & .172 & $.318^{* *}$ & 1 & \\
\hline $\mathrm{Zn}$ & .171 & -.083 & -.144 & -.114 & $.544^{* *}$ & -.162 & .065 & $.324^{* *}$ & $.223^{*}$ & $.447^{* *}$ & $.565^{* *}$ & 1 \\
\hline
\end{tabular}

$* *$ Correlation is significant at the 0.01 level (2-tailed); *Correlation is significant at the 0.05 level (2-tailed)

\section{Characteristic elemental ratios}

The characteristic ratios of the elements such as $\mathrm{Al}, \mathrm{Ca}, \mathrm{Fe}, \mathrm{Zn}, \mathrm{S}$ and $\mathrm{Pb}$ were used in order to visualize their seasonal variations and then to predict their source contributors according to the reports from Asian cities. The seasonal variations of $\mathrm{S} / \mathrm{Al}, \mathrm{Ca} / \mathrm{Al}, \mathrm{Fe} / \mathrm{Al}$ and $\mathrm{Zn} / \mathrm{Pb}$ have been plotted in the (Fig. 3). Generally, two types of seasonal trends have been noticed. The first type includes S/Al and $\mathrm{Zn} / \mathrm{Pb}$, having highest values in autumn 2016 and lowest in summer 2016. This trend depicts dominance of anthropogenic contributions such as fossil fuel combustion during low temperature months. The second type includes ratios of $\mathrm{Ca} / \mathrm{Al}$ and $\mathrm{Fe} / \mathrm{Al}$, having highest values in summer 2016 and lowest in autumn 2016. This trend predicts dominance of natural sources such as earth-crest and airborne dust during high temperature months [44].

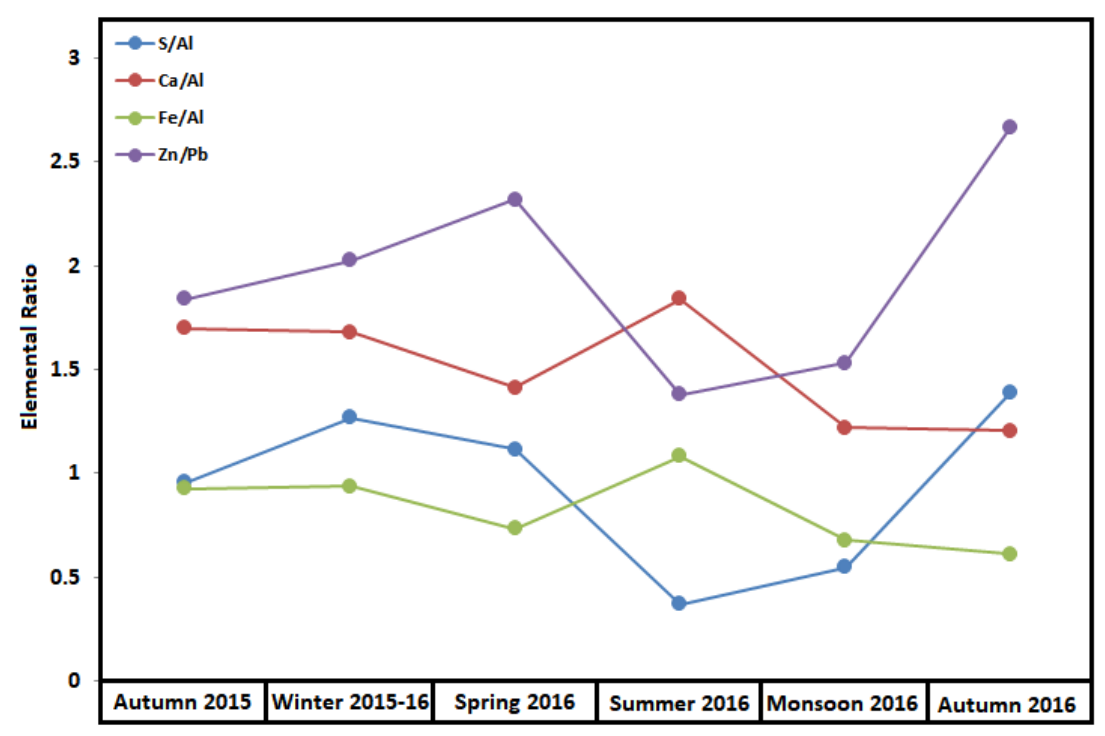

Fig. 3. The characteristic ratios of the certain elements and their seasonal variations 


\section{Enrichment factor analysis}

In order to estimate elemental contributions from sources other than natural ones, enrichment factors (EFs) of the analyzed elements were calculated. The following equation (1) has been used for this purpose:

$$
[\mathrm{EF}]=\frac{[\text { Element X/Element R] Air }}{[\text { Element X/Element R] Source }}
$$

Whereas Element $\mathrm{X}$ is the element under study and Element $\mathrm{R}$ is the element with reference to which the factor has to be calculated [45]. In the present study, Fe was used as a reference element and the data of the elemental concentrations from the source was obtained from the study of Yaroshevsky [46]. The EF values were divided into three levels. If $\mathrm{EF} \leq 1$, then natural emissions; if $1<\mathrm{EF}<10$, then mixed profiles and if $\mathrm{EF} \geq 10$, then anthropogenic contributions were considered [40]. The emission factors of the analyzed elements during different seasons have been presented in (Fig. 4). The EF values were less than 1 throughout the study for the elements such as $\mathrm{Na}, \mathrm{Al}$ and $\mathrm{Fe}$; employing discharge of these elements entirely from natural sources such as soil or the disintegration of the earth-crest [47]. The EF values of $\mathrm{K}$ were less than 1 for all the seasons except autumn 2016. In autumn 2016 additional contribution from biomass burning was deduced along with natural origin [48].

Similarly, Ba has EF values less than 1 for all the seasons except autumn 2015, spring 2016 and autumn 2016. The elements such as $\mathrm{Mg}, \mathrm{Ca}, \mathrm{Mn}$ and $\mathrm{P}$ have situation of $1<\mathrm{EF}<5$, explaining minor contributions from vehicular non-exhaust emissions and industrial dust [41]. The elements such as $\mathrm{S}$, $\mathrm{Zn}$ and $\mathrm{Pb}$ have EF values $>10$ for all the seasons, suggesting purely anthropogenic emissions from heavy duty diesel vehicles and combustion of fossil fuels [49].

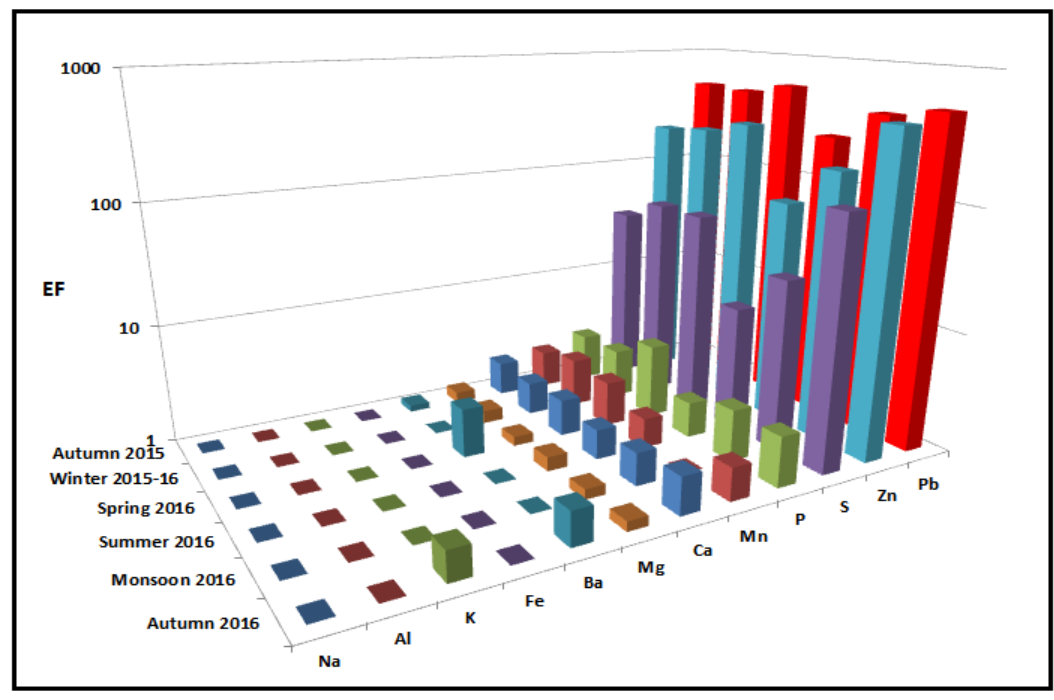

Fig. 4. The emission factors (EFs) of the analyzed elements during different seasons

\section{Principal component \& cluster analysis}

The results of the factor analysis (Varimax normalized rotation) for elements have been summarized in the (table 3), explaining a cumulative variance of $73.4 \%$. Three factor groups having Eigen-value greater than unity were inspected. In the first factor, elements such as $\mathrm{Ca}, \mathrm{Mg}, \mathrm{Fe}$ and $\mathrm{Al}$ were strongly loaded with the total variance of $40.1 \%$. These compounds have originated from the wind-blown dust $[15,13]$. In the second factor, elements such as $\mathrm{K}, \mathrm{S}, \mathrm{Zn}$ and $\mathrm{Na}$ were loaded with total variance of $24.6 \%$. The elements grouped in this factor are well-known markers of biomass burning and fossil fuel combustion $[50,51]$. The strong negative loading of temperature in this factor has justified the fact that emission intensity of these elements is more pronounced in comparatively low temperature seasons. The third factor accounted for $8.5 \%$ of the variance, having strong loading of $\mathrm{Pb}$ and negative strong loading of humidity variable. This factor explains indirect emissions of lead 
from vehicular traffic [14]. Pb emitted from vehicle exhaust is settled in the road side and entry of this element in air is more obvious in the dry conditions.

Table 3

VARIMAX ROTATED PCA LOADINGS FOR ELEMENTS IN PM10

\begin{tabular}{|c|c|c|c|c|}
\hline Variable & Factor 1 & Factor 2 & Factor 3 & Communality \\
\hline $\mathrm{Ca}$ & $0.934^{*}$ & -0.163 & 0.255 & 0.964 \\
\hline $\mathrm{Mg}$ & $0.927^{*}$ & -0.207 & 0.241 & 0.960 \\
\hline $\mathrm{Fe}$ & $0.926^{*}$ & -0.171 & 0.285 & 0.967 \\
\hline $\mathrm{Al}$ & $0.891^{*}$ & 0.265 & -0.035 & 0.865 \\
\hline $\mathrm{Mn}$ & $0.768^{*}$ & 0.076 & 0.501 & 0.847 \\
\hline $\mathrm{Ba}$ & 0.383 & 0.009 & -0.110 & 0.159 \\
\hline $\mathrm{K}$ & 0.191 & $0.903^{*}$ & 0.080 & 0.858 \\
\hline $\mathrm{S}$ & 0.036 & $0.878^{*}$ & -0.047 & 0.774 \\
\hline Temperature & 0.276 & $-0.739^{*}$ & 0.027 & 0.623 \\
\hline $\mathrm{Zn}$ & -0.118 & $0.721^{*}$ & 0.250 & 0.595 \\
\hline $\mathrm{Na}$ & 0.597 & $0.636^{*}$ & 0.250 & 0.824 \\
\hline $\mathrm{Pb}$ & -0.184 & 0.336 & $0.719^{*}$ & 0.663 \\
\hline Humidity & -0.316 & 0.130 & $-0.677^{*}$ & 0.576 \\
\hline $\mathrm{P}$ & 0.458 & 0.202 & 0.596 & 0.606 \\
\hline Eigenvalue & 5.624 & 3.455 & 1.202 & \\
\hline Variance $(\%)$ & 40.169 & 24.681 & 8.589 & \\
\hline
\end{tabular}

Three factors with eigen values exceeding unity were included.

The absolute factor loading greater than \pm 0.60 for each variable is shown with asteric.

The cluster analysis (Ward's linkage) verified the results of PCA to some extent as revealed by a dendrogram in the (Fig. 5). In total, three clusters were appeared. In the first cluster elements from earth-crest such as $\mathrm{Fe}, \mathrm{Mg}, \mathrm{Ca}, \mathrm{Mn}, \mathrm{Al}$ and $\mathrm{P}$ were gathered. In the second cluster only $\mathrm{Ba}$ was placed. In the third cluster elements such as $\mathrm{K}, \mathrm{Na}, \mathrm{S}, \mathrm{Zn}$ and $\mathrm{Pb}$ were assembled. All these elements are emitted from biomass burning, coal based industries and vehicular exhaust/non-exhaust emissions [52, $19]$.

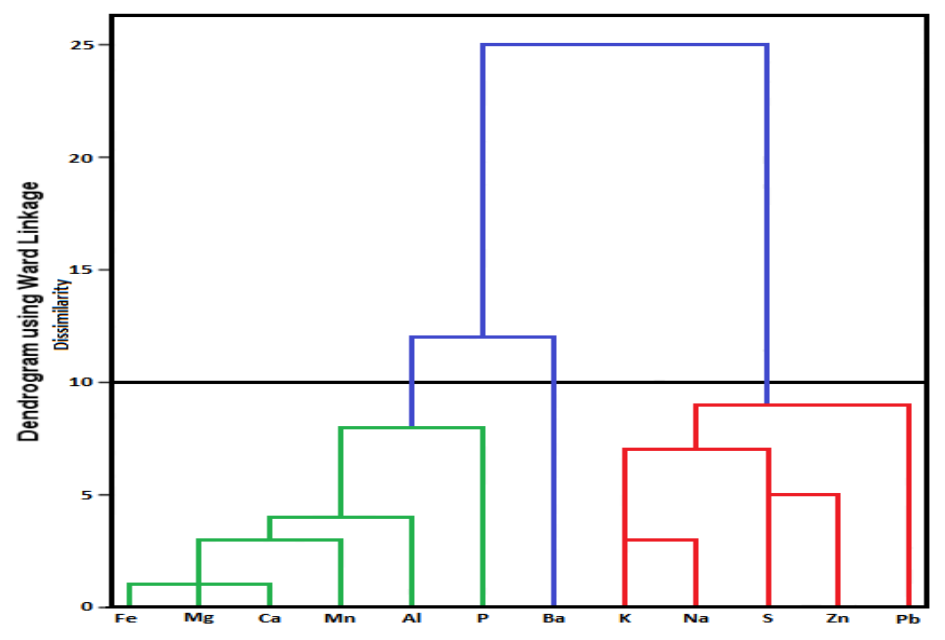

Fig. 5. Dendrogram of the Cluster analysis (Ward's linkage) for the elements in $\mathrm{PM}_{10}$

\section{Health risk assessment}

A health risk caused by non-carcinogenic trace elements such as $\mathrm{Pb}, \mathrm{Zn}$ and $\mathrm{Mn}$ was assessed according to the method specified by US-EPA [40]. The risk assessment was conducted by using the mean concentrations of the selected elements and single exposure route via inhalation was assumed for calculations. The Average Daily Dose (ADD) in $\mathrm{mg} \cdot \mathrm{kg}^{-1} \cdot \mathrm{d}^{-1}$ units was first calculated by using the following formula (2) which later on would be used for the calculation of Health Risk (R): 
Whereas $\mathrm{C}=$ Concentration of the elements in $\mathrm{mg} \cdot \mathrm{m}^{-3}, \mathrm{IR}=$ Inhalation Rate in $\mathrm{m}^{3} \cdot \mathrm{d}^{-1}$ (15.2 for men, 11.3 for women and 8.7 for children), $\mathrm{ED}=$ Exposure Duration in days (30 years for adults and 18 years for the children), BW = Body weight in $\mathrm{kg}$ (70 for men, 60 for women and 36 for children) and AT $=$ Average Time in days ( $30 \times 365$ days for adults and $18 \times 365$ days for children).

The Health Risk (R) to the population exposed over a 70-years life span was calculated by using the following formula (3):

$$
\mathrm{R}=\left[\mathrm{ADD} \times 10^{-6}\right] /[\mathrm{RfD} \times 70]
$$

Whereas RfD $=$ Reference Dose in mg.kg ${ }^{-1} \cdot \mathrm{d}^{-1}\left(4.30 \times 10^{-4}\right.$ for $\mathrm{Pb} ; 3.00 \times 10^{-4}$ for $\mathrm{Mn}$ and $1.00 \times 10^{-2}$ for $\mathrm{Zn}$ ). The results of the assessment have been shown in the (Fig. 6). The Health Risk (R) values were out of the acceptable limits $\left(10^{-6}\right.$ per year) fixed by US-EPA, due to high ADD values. The children were more prone to the health risk as compared to the adults and risk levels to the elemental exposures were observed in the order of $\mathrm{Pb}>\mathrm{Mn}>\mathrm{Zn}$.

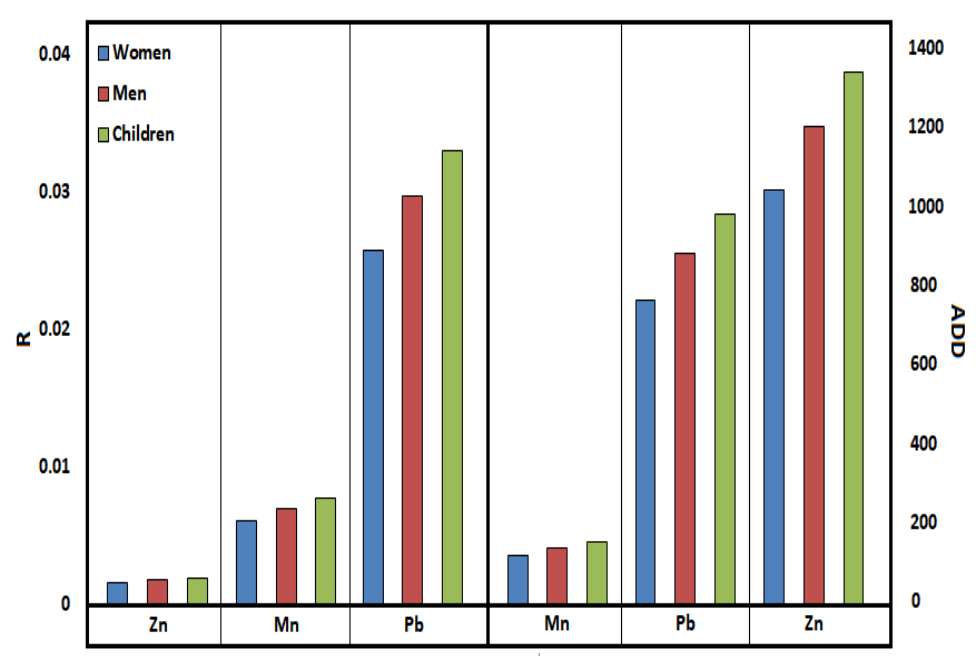

Fig. 6. The Health Risk (R) and Average Daily Dose (ADD) for the selected elements

\section{Conclusions}

The statistical analysis of $\mathrm{PM}_{10}$ size fraction and elemental contents revealed distinct seasonal variations. Many elements either exhibited same or opposite distribution patterns, indicating their common source of origin. The low temperature conditions during autumn and winter seasons preferred the distribution of elements such as $\mathrm{S}, \mathrm{K}, \mathrm{Zn}$ and Na. On the other hand, high temperature and dry conditions during spring and summer seasons favored the distribution of elements such as $\mathrm{Ca}, \mathrm{Mg}, \mathrm{Al}$, $\mathrm{Fe}, \mathrm{P}, \mathrm{Mn}$ and $\mathrm{Ba}$. The data spread around mean values of elements indicate contributions from some random sources as well. The elemental concentrations appeared in the present study were higher than the local and international inventories and were crossing the limits fixed by environment protection and regulatory bodies. The EF values showed that elements such as $\mathrm{S}, \mathrm{Zn}$ and $\mathrm{Pb}$ have emerged dominantly from the anthropogenic sources. The study revealed airborne soil, industrial \& fugitive dust from construction activities, biomass burning, heavy duty diesel vehicles, fossil fuel combustion and vehicular non-exhaust (wear \& tear of engine, tires and brakes) emissions are key factor involved in deteriorating the local air quality. The results of the health risk assessment unveiled that children were more prone to danger imposed by non-carcinogenic elements in the order of $\mathrm{Pb}>\mathrm{Mn}>\mathrm{Zn}$.

\section{Abreviations}

$\begin{array}{ll}\text { A.S.L } & =\text { Above Sea Level } \\ \text { ADD } & =\text { Average Daily Dose } \\ \text { AT } & =\text { Average Time } \\ \text { BDL } & =\text { Below Detection Limit } \\ \text { BW } & =\text { Body Weight }\end{array}$




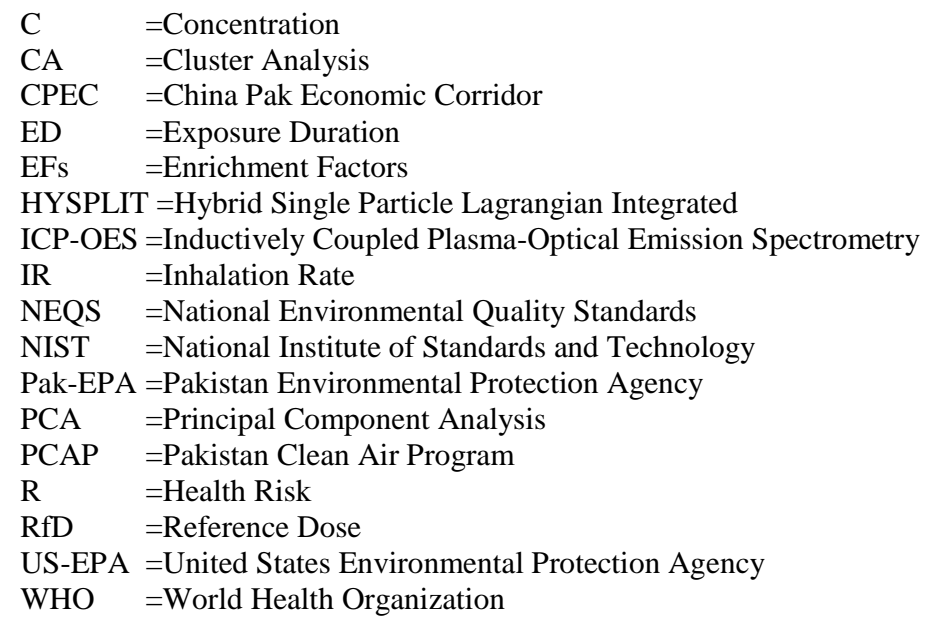

Acknowledgement: The authors are thankful to the Higher Education Commission (HEC), Government of Pakistan for providing necessary funds through International Research Support Initiative Program (IRSIP) in order to complete this research work.

\section{References}

1. JICKELLS, T., MOORE, C.M., Annu. Rev. Ecol. Evol. Syst., 46, 2015, p. 481

2. MARTINELLI, N., OLIVIERI, O., GIRELLI, D., Eur. J. Intern. Med., 24, 2013, p. 295

3. BRUNEKREEF, B., BEELEN, R., HOEK, G., SCHOUTEN, L., BAUSCH, G.S., FISCHER, P., ARMSTRONG, B., HUGHES, E., JERRETT, M., VAN DEN, B.P., Res. Rep. Health. Eff. Inst., 139, 2009, p. 73

4.BOLDO, E., LINARES, C., LUMBRERAS, J., BORGE, R., NARROS, A., PÉREZ, J.C., NAVARRO, P.F., GÓMEZ, B.P., ARAGONÉS, N., RAMIS, R., POLLÁN, M., MORENO, T., KARANASIOU, A., ABENTE, G.L., Environ. Int., 37, 2011, p. 342

5. CALVO, A.I., ALVES, C., CASTRO, A., PONT, V., VICENTE, A.M., FRAILE, R., Atmospheric. Res., 120, 2013 , p. 1 6. JIMENEZ, J.L., CANAGARATNA, M.R., DONAHUE, N.M., PREVOT, A.S.H., ZHANG, Q., KROLL, J.H., CARLO, P.F.D., ALLAN, J.D., COE, H., Science, 326, 2009, p. 1525

7. KIM, J.J., HUEN, K., ADAMS, S., SMORODINSKY, S., HOATS, A., MALIG, B., LIPSETT, M., OSTRO, B., Environ. Health. Perspect., 116, 2008, p. 1274

8.KHAN, M.F., SULONG, N.A., LATIF, M.T., NADZIR, M.S.M., AMIL, N., HUSSAIN, D.F.M., J. Geophys. Res. Atmos., 121, 2016, p. 14589

9.SHAH, M.H., SHAHEEN, N., JAFFAR, M., KHALIQUE, A., TARIQ, S.R., MANZOOR, S., J. Environ. Manage., 78, 2006, p. 128

10. WAHID, N., LATIF, M., SUAN, L., DOMINICK, D., SAHANI, M., JAAFAR, S., TAHIR, N.M., Bull. Environ. Contam. Toxicol., 92, 2014, p. 317

11. FREITAS, M., PACHECO, A., VERBURG, T., WOLTERBEEK, H., Environ. Monit. Assess., 162, 2010, p. 113

12. MAVROIDIS, I., CHALOULAKOU, A., Int. J. Environ. Pollut., 41, 2010, p. 124

13. SHAH, M.H., SHAHEEN, N., Atmos. Res., 95, 2010, p. 210

14. ZEREINI, F., ALT, F., MESSERSCHMIDT, J., WISEMAN, C., FELDMANN, I., BOHLEN, A.V., MULLER, J., LIEBL, K., PUTTMANN, W., Environ. Sci. Technol., 39, 2005, p. 2983

15. HAO, Y., GUO, Z., YANG, Z., FANG, M., FENG, J., Atmos. Res., 85, 2007, p. 27

16. KHAN, M.F., SHIRASUNA, Y., HIRANO, K., MASUNAGA, S., Atmos. Res., 96, 2010, p. 159

17. YUSUP, Y., ALKARKHI, A.F., Chem. Ecol., 27, 2011, p. 273

18. ALVI, M.U., CHISHTIE, F., SHAHID, I., MAHMUD, T., HUSSAIN, R., Clean., 46, 2018, p. 1600773

19. MANOLI, E., VOUTSA, D., SAMARA, C., Atmos. Environ., 36, 2002, p. 949

20. SHAH, M.H., SHAHEEN, N., NAZIR, R., Atmos. Pollut. Res., 3, 2012, p. 39

21. MUKHTAR, A., LIMBECK, A., Int. J. Environ. Anal. Chem., 92, 2012, p. 496

22. ALAM, K., IQBAL, M.J., BLASCHKE, T., QURESHI, S., KHAN, G., Adv. Space. Res., 46, 2010, p. 1162

23.SHAHID, I., KISTLER, M., MUKHTAR, A., GHAURI, B.M., RAMIREZ, C., CRUZ, S., BAUER, H., PUXBAUM, H., Atmos. Environ., 128, 2016, p. 114

24.AWASTHI, A., AGARWAL, R., MITTAL, S.K., SINGH, N., SINGH, K., GUPTA, P.K., J. Environ. Monit., 13, 2011 , p. 1073

25. GUPTA, P., CHRISTOPHER, S.A., BOX, M.A., BOX, G.P., Int. J. Remote. Sens., 28, 2007, p. 4483

26.HOPKE, P.K., COHEN, D.D., BEGUM, B.B., BISWAS, S.K., NI, B., PANDIT, G.G., SANTOSO, M.M., CHUNG, Y.S., DAVY, P., MARKWITZ, A., Sci. Total Environ., 404, 2008, p. 103

27. SINGH, R.P., KASKAOUTIS, D.G., Eos. Trans., 95, 2014, p. 333

28. ALAM, K., KHAN, R., SOOROSHIAN, A., BLASCHKE, T., BIBI, S., BIBI, H., Aerosol Air Qual. Res., 18, 2018 , p. 1331

29. CHAKRABORTY, A., GUPTA, T., Aerosol Air Qual. Res., 10, 2010, p. 433

30.PAKBIN, P., HUDDA, N., CHEUNG, K.L., MOORE, K.F., SIOUTAS, C., Aerosol. Sci. $\quad$ Technol., 44, 2010, p. 514

31.SHARMA, M., DIMITRIS, G., RAMESH, P., Aerosol Air Qual. Res., 14, 2014, p. 608 
32. SHAHID, M.Z., LIAO, H., LI, J., SHAHID, I., LODHI, A., MANSHA, M., Aerosol Air

Qual. Res., 15, 2015, p. 1580

33.BISWAS, K.F., GHAURI, B.M., HUSAIN, L., Atmos. Environ., 42, 2008, p. 7775

34. STONE, E., SCHAUER, J., QURAISHI, T.A., MAHMOOD, A., Atmos. Environ., 44,

2010, p. 1062

35.BUDHAVANT, K.B., RAO, P.S.P., SAFAI, P.D., AH, K., Aerosol Air Qual. Res., 9, 2009, p. 65

36. JAVED, W., WEXLER, A.S., MURTAZA, G., IQBAL, M.M., ZHAO, Y., NAZ, T., Clean., 44, 2016, p. 1

37. ALAM, K., MUKHTAR, A., SHAHID, I., BLASCHKE, T., MAJID, H., RAHMAN, S., KHAN, R., Aerosol Air Qual. Res., 14, 2014, p. 1851

38. AHMED, F., SHAH, M.H., SHAHEEN, N., Environ. Earth Sci., 71, 2014, p. 817

39. SALAM, A., BAUER, H., KASSIN, K., ULLAH, S.M., PUXBAUM, H., Atmos. Environ., 37, 2003, p. 2517

40. CHENG, X., HUANG, Y., ZHANG, S.P., NI, S.J., LONG, Z.J., Aerosol Air Qual. Res.,

18, 2018, p. 357

41.THEODOSI, C., IM, U., BOUGIATIOTI, A., ZARMPAS, P., YENigun, O., MIHALOPOUlOS, N., Sci. Total. Environ., 408, 2010, p. 2482

42.VECCHI, R., MARCAZZAN, G., VALLI, G., Atmos. Environ., 41, 2007, p. 2136

43. ZHANG, J., WU, L., FANG, X., LI, F., YANG, Z., WANG, T., MAO, H., WEI, E., Aerosol Air Qual. Res., 18, 2018, p. 1817

44.CAO, J., SHEN, Z., CHOW, J.C., QI, G., WATSON, J.G., Particuology., 7, 2009, p. 161

45.ELHADI, R.E., ABDULlAH, A.M., ABDUlLAH, A.H., ASHAARI, Z.H., KHAN, M.F., Aerosol Air Qual. Res., 18, 2018, p. 1148

46. YAROSHEVSKY, A.A., Geochem. Int., 44, 2006, p. 48

47.BHUYAN, P., DEKA, P., PRAKASH, A., BALACHANDRAN, S., HOQUE, R.R., Environ. Pollut., 234, 2018, p. 997

48. HAO, Y., MENG, X., YU, X., LEI, M., LI, W., SHI, F., YANG, W., ZHANG, S., XIE, S., Atmos. Res., 213, 2018 , p. 550

49.ALAM, K., RAHMAN, N., KHAN, H.U., HAQ, B.S., RAHMAN, S., Aerosol Air Qual. Res., 15, 2015, p. 634

50. QUITERIO, S.L., SOUSA, C.R.S., ARBILLA, G., ESCALEIRA, V., Atmos. Environ., 38, 2004, p. 321

51. SHAHEEN, N., SHAH, M.H., JAFFAR, M., Water Air Soil. Pollut., 164, 2005, p. 275

52. KHILLARE, P.S., BALACHANDRAN, S., MEENA, B.R., Environ. Monit. Assess., 90, 2004, p. 1

Manuscript received: 18.06 .2019 
Table $1 S$

SUMMARY OF THE STANDARDS PROVIDED BY PAK-EPA, US-EPA AND WHO

\begin{tabular}{|c|c|c|c|c|c|c|c|}
\hline \multirow{3}{*}{ Pollutants } & \multicolumn{3}{|c|}{ NEQS by Pak-EPA } & \multicolumn{2}{|c|}{ NAAQS by US-EPA } & \multicolumn{2}{|c|}{ WHO } \\
\hline & \multirow{2}{*}{$\begin{array}{l}\text { Average } \\
\text { Time }\end{array}$} & \multicolumn{2}{|c|}{ Concentration } & \multirow{2}{*}{$\begin{array}{l}\text { Average } \\
\text { Time }\end{array}$} & \multirow{2}{*}{ Concentration } & \multirow{2}{*}{$\begin{array}{l}\text { Average } \\
\text { Time }\end{array}$} & \multirow{2}{*}{ Concentration } \\
\hline & & 2009 & 2012 & & & & \\
\hline \multirow{2}{*}{$\begin{array}{c}\text { Sulphur Dioxide }\left(\mathrm{SO}_{2}\right) \\
\mu \mathrm{g} \mathrm{m}^{-3}\end{array}$} & $24 \mathrm{Hrs}^{\mathrm{b})}$ & 120 & 120 & $24 \mathrm{Hrs}$ & $140^{\mathrm{d})}$ & $24 \mathrm{Hrs}$ & 20 \\
\hline & 1 Year $^{\mathrm{b})}$ & 80 & 80 & 1 Year & $30^{\mathrm{d})}$ & 1 Year & 50 \\
\hline \multirow{2}{*}{$\begin{array}{l}\text { Oxides of Nitrogen as } \\
\text { (NO) } \mu \mathrm{g} \mathrm{m}^{-3}\end{array}$} & $24 \mathrm{Hrs}^{\mathrm{b})}$ & 40 & 40 & \multirow{2}{*}{-} & \multirow[b]{2}{*}{-} & \multirow{2}{*}{-} & \multirow{2}{*}{-} \\
\hline & 1 Year $^{\mathrm{b})}$ & 40 & 40 & & & & \\
\hline \multirow{2}{*}{$\begin{array}{l}\text { Oxides of Nitrogen as } \\
\left(\mathrm{NO}_{2}\right) \mu \mathrm{g} \mathrm{m}^{-3}\end{array}$} & $24 \mathrm{Hrs}^{\mathrm{b})}$ & 80 & 80 & \multirow{2}{*}{1 Year } & \multirow{2}{*}{$53^{\mathrm{d})}$} & $1 \mathrm{Hr}$ & 200 \\
\hline & 1 Year $^{\mathrm{b})}$ & 40 & 40 & & & 1 Year & 40 \\
\hline \multirow{2}{*}{$\mathrm{O}_{3} \mu \mathrm{g} \mathrm{m}^{-3}$} & \multirow{2}{*}{$1 \mathrm{Hr}$} & \multirow{2}{*}{180} & \multirow{2}{*}{130} & $1 \mathrm{Hr}$ & $120^{\mathrm{d})}$ & \multirow{2}{*}{$8 \mathrm{Hrs}$} & \multirow{2}{*}{100} \\
\hline & & & & $8 \mathrm{Hrs}$ & $80^{\mathrm{d})}$ & & \\
\hline \multirow{2}{*}{$\begin{array}{l}\text { Suspended Particulate } \\
\text { Matter (SPM) } \mu \mathrm{g} \mathrm{m}^{-3}\end{array}$} & $24 \mathrm{Hrs}^{\mathrm{b})}$ & 550 & 500 & \multirow{2}{*}{-} & \multirow{2}{*}{-} & \multirow{2}{*}{$24 \mathrm{Hrs}$} & \multirow{2}{*}{120} \\
\hline & 1 Year $\left.^{a}\right)$ & 400 & 360 & & & & \\
\hline \multirow{2}{*}{$\begin{array}{l}\text { Respirable Particulate } \\
\text { Matter (PM10) } \mu \mathrm{g} \mathrm{m}^{-3}\end{array}$} & $24 \mathrm{Hrs}^{\mathrm{b})}$ & 250 & 150 & $24 \mathrm{Hrs}$ & 150 & $24 \mathrm{Hr}$ & 50 \\
\hline & 1 Year $^{\mathrm{a})}$ & 200 & 120 & 1 Year & 50 & 1 Year & 20 \\
\hline \multirow{4}{*}{$\begin{array}{l}\text { Reparable Particulate } \\
\text { Matter (PM2.5) } \mu \mathrm{g} \mathrm{m}^{-3}\end{array}$} & $1 \mathrm{Hr}$ & 25 & 15 & \multirow{3}{*}{$24 \mathrm{Hrs}$} & & $1 \mathrm{Hr}$ & 1 \\
\hline & & & & & 65 & & \\
\hline & $24 \mathrm{Hrs}^{\mathrm{b})}$ & 40 & 35 & & & $24 \mathrm{Hrs}$ & 25 \\
\hline & 1 Yeara) & 25 & 15 & 1 Year & 15 & $1 \mathrm{Veor}$ & 10 \\
\hline & $24 \mathrm{Hrs}^{\mathrm{b})}$ & 2.0 & 1.5 & & & & \\
\hline Lead $(\mathrm{Pb}) \mu \mathrm{g} \mathrm{m}^{-3}$ & 1 Year $^{\mathrm{a})}$ & 1.5 & 1.0 & 3 months & 1.5 & 1 Year & 0.5 \\
\hline Carbon Monoxide (CO) & $8 \mathrm{Hrs}^{\mathrm{b})}$ & 5.0 & 5.0 & $1 \mathrm{Hr}$ & $35^{\mathrm{c})}$ & $1 \mathrm{Hr}$ & 30 \\
\hline $\mathrm{mg} \mathrm{m}^{-3}$ & $24 \mathrm{Hrs}^{\mathrm{b})}$ & 10 & 10 & $8 \mathrm{Hrs}$ & $9^{c)}$ & $8 \mathrm{Hrs}$ & 10 \\
\hline $\begin{array}{l}\text { a) Annual arithmet } \\
\text { b) } 24 \text { hourly/8 ho }\end{array}$ & nean of mi & ld be $n$ & $\begin{array}{r}\text { measur } \\
\text { it } \\
98 \% \mathrm{o} \\
\text { conse } \\
\text { c) } \mathrm{Va} \\
\text { d) } \mathrm{Va}\end{array}$ & $\begin{array}{l}\text { ents in a ye } \\
\text { rval } \\
\text { he year. } 2 \% \\
\text { ive days } \\
\text { in ppm } \\
\text { e in ppb }\end{array}$ & $\begin{array}{l}\text { taken twice a w } \\
\text { the time, it may }\end{array}$ & x 24 hourl & $\begin{array}{l}\text { uniform } \\
\text { on two }\end{array}$ \\
\hline
\end{tabular}

Table 2S

DESCRIPTIVE DATA OF THE METEOROLOGICAL VARIABLES EXIST IN THE FAISALABAD CITY

\begin{tabular}{|c|c|c|c|c|c|c|c|}
\hline Season & Duration & $\begin{array}{c}\text { Number of } \\
\text { Samples } \\
\text { collected }\end{array}$ & $\begin{array}{c}\text { Average } \\
\text { Temperature } \\
\left({ }^{\circ} \mathrm{C}\right)\end{array}$ & $\begin{array}{c}\text { Average } \\
\text { Relative } \\
\text { Humidity } \\
(\%)\end{array}$ & $\begin{array}{c}\text { Average } \\
\text { Precipitation } \\
(\mathrm{mm})\end{array}$ & $\begin{array}{c}\text { Surface } \\
\text { Pressure } \\
(\mathrm{hPa})\end{array}$ & $\begin{array}{c}\text { Average } \\
\text { Aerosol } \\
\text { Optical } \\
\text { Depth } \\
(\mathrm{AOD})\end{array}$ \\
\hline $\begin{array}{c}\text { Autumn } \\
2015\end{array}$ & $\begin{array}{c}16 \text { Sep to } \\
14 \text { Nov }\end{array}$ & 21 & 26.62 & 44.02 & 14 & 989.89 & 0.767 \\
\hline $\begin{array}{c}\text { Winter } \\
2015-16\end{array}$ & $\begin{array}{c}\text { 15 Nov to } \\
\text { 15 Feb }\end{array}$ & 26 & 18.16 & 44.50 & 16 & 995.59 & 0.704 \\
\hline $\begin{array}{c}\text { Spring 2016 } \\
\text { 16 Feb to } \\
\text { 15 Apr }\end{array}$ & 19 & 23.74 & 40.57 & 38 & 990.94 & 0.546 \\
\hline $\begin{array}{c}\text { Summer } \\
2016\end{array}$ & $\begin{array}{c}16 \text { Apr to } \\
\text { 30 Jun }\end{array}$ & 19 & 34.40 & 33.74 & 45 & 981.17 & 0.769 \\
\hline $\begin{array}{c}\text { Monsoon } \\
2016\end{array}$ & $\begin{array}{c}\text { 01 Jul to 15 } \\
\text { Sep }\end{array}$ & 15 & 33.48 & 59.67 & 95 & 979.38 & 0.366 \\
\hline $\begin{array}{c}\text { Autumn } \\
2016\end{array}$ & $\begin{array}{c}\text { 16 Sep to } \\
\text { 14 Nov }\end{array}$ & 17 & 28.16 & 45.53 & 13 & 987.72 & 0.914 \\
\hline
\end{tabular}


Table 3S

THE AVERAGE CONCENTRATIONS $\left(\mu \mathrm{g} . \mathrm{m}^{-3}\right)$ OF PM${ }_{10}$ AND ELEMENTS ALONG WITH THEIR SEASONAL VARIATIONS

\begin{tabular}{|c|c|c|c|c|c|c|c|c|c|c|c|c|c|c|}
\hline \multirow[t]{2}{*}{ Specie } & \multicolumn{2}{|c|}{ Overall } & \multicolumn{2}{|c|}{ Autumn 2015} & \multicolumn{2}{|c|}{ Winter 2015-16 } & \multicolumn{2}{|c|}{ Spring 2016} & \multicolumn{2}{|c|}{ Summer 2016} & \multicolumn{2}{|c|}{ Monsoon 2016} & \multicolumn{2}{|c|}{ Autumn 2016} \\
\hline & $\operatorname{Avg} \pm \mathrm{SD}$ & Range & $\operatorname{Avg} \pm \mathrm{SD}$ & Range & $\mathrm{Avg} \pm \mathrm{SD}$ & Range & $\operatorname{Avg} \pm \mathrm{SD}$ & Range & $\operatorname{Avg} \pm S D$ & Range & $\operatorname{Avg} \pm \mathrm{SD}$ & Range & $\operatorname{Avg} \pm S D$ & Range \\
\hline $\mathrm{PM}_{10}$ & $744 \pm 392$ & $177-2064$ & $622 \pm 277$ & $201-1138$ & $966 \pm 253$ & $505-1413$ & $612 \pm 338$ & $177-1340$ & $757 \pm 301$ & $270-1284$ & $283 \pm 76$ & $207-475$ & $1098 \pm 454$ & $550-2064$ \\
\hline $\mathrm{Al}$ & $\begin{array}{c}22.13 \pm 10.5 \\
0 \\
\end{array}$ & $7.92-61.06$ & $\begin{array}{c}14.71 \pm 4.0 \\
2 \\
\end{array}$ & $7.92-22.09$ & $\begin{array}{c}21.95 \pm 5.6 \\
7 \\
\end{array}$ & $\begin{array}{l}11.12- \\
33.64 \\
\end{array}$ & $\begin{array}{c}17.05 \pm 5.5 \\
3 \\
\end{array}$ & $\begin{array}{l}10.01- \\
30.99 \\
\end{array}$ & $\begin{array}{c}33.30 \pm 14 \\
56 \\
\end{array}$ & $\begin{array}{c}13.49- \\
61.06 \\
\end{array}$ & $\begin{array}{c}17.93 \pm 4.7 \\
1 \\
\end{array}$ & $\begin{array}{l}12.29- \\
29.72 \\
\end{array}$ & $\begin{array}{c}28.45 \pm 10 \\
16 \\
\end{array}$ & $\begin{array}{l}13.13- \\
51.95 \\
\end{array}$ \\
\hline $\mathrm{Ba}$ & $0.51 \pm 0.88$ & $0.01-4.68$ & $0.39 \pm 0.61$ & $0.03-2.03$ & $0.15 \pm 0.19$ & $0.02-0.67$ & $0.71 \pm 0.85$ & $0.07-2.48$ & $0.84 \pm 1.34$ & $0.05-4.68$ & BDL & BDL & $0.68 \pm 0.62$ & $0.07-2.59$ \\
\hline $\mathrm{Ca}$ & $\begin{array}{c}33.59 \pm 18.6 \\
7 \\
\end{array}$ & $\begin{array}{l}10.12- \\
116.45 \\
\end{array}$ & $\begin{array}{c}25.10 \pm 8.4 \\
2 \\
\end{array}$ & $\begin{array}{l}12.53- \\
39.81 \\
\end{array}$ & $\begin{array}{c}36.92 \pm 11 \\
89 \\
\end{array}$ & $\begin{array}{l}13.26- \\
62.57 \\
\end{array}$ & $\begin{array}{c}23.88 \pm 9.3 \\
7 \\
\end{array}$ & $\begin{array}{c}10.53- \\
47.98 \\
\end{array}$ & $\begin{array}{c}60.58 \pm 25 \\
01 \\
\end{array}$ & $\begin{array}{c}25.70- \\
116.4 \\
\end{array}$ & $\begin{array}{c}21.88 \pm 6.9 \\
1 \\
\end{array}$ & $\begin{array}{l}10.12- \\
40.66 \\
\end{array}$ & $\begin{array}{c}30.24 \pm 9.2 \\
9 \\
\end{array}$ & $\begin{array}{l}13.51- \\
47.19 \\
\end{array}$ \\
\hline $\mathrm{Fe}$ & $\begin{array}{c}18.77 \pm 11.4 \\
7 \\
\end{array}$ & $4.59-65.68$ & $\begin{array}{c}13.76 \pm 4.7 \\
7\end{array}$ & $4.59-21.69$ & $\begin{array}{c}20.94 \pm 7.6 \\
5\end{array}$ & $6.46-41.79$ & $\begin{array}{c}12.61 \pm 5.1 \\
2 \\
\end{array}$ & $4.90-24.13$ & $\begin{array}{c}35.99 \pm 15 \\
25\end{array}$ & $\begin{array}{l}14.17- \\
65.68 \\
\end{array}$ & $\begin{array}{c}12.11 \pm 3.5 \\
8\end{array}$ & $6.52-21.97$ & $\begin{array}{c}15.30 \pm 4.5 \\
5\end{array}$ & $7.18-23.43$ \\
\hline $\mathrm{K}$ & $12.38 \pm 8.07$ & $1.72-48.34$ & $\begin{array}{c}11.82 \pm 5.1 \\
5 \\
\end{array}$ & $4.64-22.32$ & $\begin{array}{c}16.39 \pm 4.9 \\
8 \\
\end{array}$ & $6.77-26.55$ & $\begin{array}{c}10.47 \pm 5.6 \\
1\end{array}$ & $3.19-26.44$ & $8.35 \pm 1.75$ & $5.51-11.69$ & $3.47 \pm 1.02$ & $1.72-5.61$ & $\begin{array}{c}21.67 \pm 11 \\
53\end{array}$ & $7.78-48.34$ \\
\hline $\mathrm{Mg}$ & $10.42 \pm 7.06$ & $2.62-40.02$ & $7.30 \pm 2.32$ & $2.95-10.85$ & $\begin{array}{c}11.80 \pm 4.6 \\
9\end{array}$ & $3.56-23.40$ & $6.55 \pm 2.78$ & $2.62-13.71$ & $\begin{array}{c}21.01 \pm 9.6 \\
0\end{array}$ & $7.09-40.02$ & $6.56 \pm 2.67$ & $3.07-15.20$ & $8.15 \pm 2.75$ & $3.19-13.21$ \\
\hline Mn & $0.66 \pm 0.47$ & $0.07-2.36$ & $0.53 \pm 0.35$ & $0.11-1.26$ & $0.92 \pm 0.39$ & $0.24-1.89$ & $0.54 \pm 0.33$ & $0.07-1.37$ & $1.12 \pm 0.54$ & $0.32-2.36$ & $0.20 \pm 0.10$ & $0.09-0.37$ & $0.48 \pm 0.27$ & $0.19-1.10$ \\
\hline $\mathrm{Na}$ & $4.23 \pm 1.94$ & $1.35-10.97$ & $3.69 \pm 1.22$ & $1.74-6.15$ & $5.30 \pm 1.61$ & $3.05-9.23$ & $3.54 \pm 1.69$ & $1.39-7.92$ & $4.76 \pm 1.47$ & $2.39-7.65$ & $2.10 \pm 1.28$ & $1.35-6.65$ & $5.35 \pm 2.19$ & $2.72-10.97$ \\
\hline $\mathrm{P}$ & $0.96 \pm 0.44$ & $0.29-3.55$ & $0.71 \pm 0.27$ & $0.29-1.37$ & $1.07 \pm 0.31$ & $0.61-1.75$ & $1.05 \pm 0.47$ & $0.42-2.29$ & $1.35 \pm 0.59$ & $0.76-3.55$ & $0.68 \pm 0.15$ & $0.35-0.96$ & $0.83 \pm 0.24$ & $0.45-1.37$ \\
\hline $\mathrm{Pb}$ & $3.93 \pm 2.22$ & $1.02-9.86$ & $3.34 \pm 1.93$ & $1.93-8.11$ & $5.04 \pm 2.45$ & $1.48-9.86$ & $4.51 \pm 2.10$ & $2.07-7.92$ & $3.42 \pm 1.16$ & $1.86-5.25$ & $2.59 \pm 0.96$ & $1.67-3.91$ & $4.18 \pm 2.79$ & $1.02-8.88$ \\
\hline $\mathrm{S}$ & $\begin{array}{c}20.56 \pm 21.0 \\
4 \\
\end{array}$ & $\begin{array}{c}4.14- \\
145.11 \\
\end{array}$ & $\begin{array}{c}13.26 \pm 5.2 \\
5 \\
\end{array}$ & $5.69-21.52$ & $\begin{array}{c}25.70 \pm 16 \\
87\end{array}$ & $\begin{array}{l}10.23- \\
72.51 \\
\end{array}$ & $\begin{array}{c}19.95 \pm 14 \\
99\end{array}$ & $4.20-61.79$ & $\begin{array}{c}10.99 \pm 3.3 \\
7 \\
\end{array}$ & $6.41-18.32$ & $9.39 \pm 2.43$ & $4.14-12.96$ & $\begin{array}{c}43.25 \pm 38 \\
28\end{array}$ & $\begin{array}{c}8.33- \\
145.11 \\
\end{array}$ \\
\hline $\mathrm{Zn}$ & $5.54 \pm 5.25$ & $0.99-37.71$ & $4.33 \pm 2.79$ & $1.07-11.33$ & $6.88 \pm 4.96$ & $1.12-21.44$ & $6.02 \pm 4.40$ & $0.87-13.89$ & $3.27 \pm 2.28$ & $1.38-11.04$ & $3.19 \pm 2.07$ & $1.47-9.89$ & $9.14 \pm 9.10$ & $1.61-37.71$ \\
\hline
\end{tabular}

BDL $=$ Below Detection Limit 
NOAA HYSPLIT MODEL
Backward trajectories ending at 1200 UTC 28 Sep 15

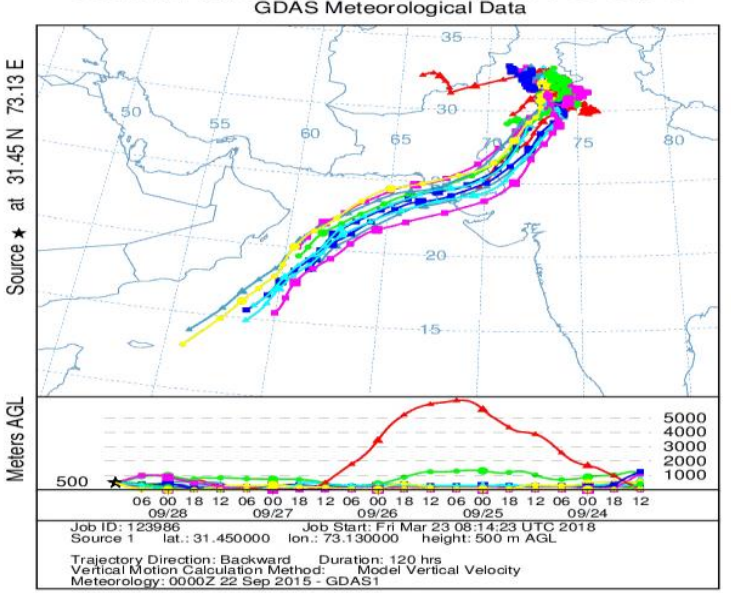

NOAA HYSPLIT MODEL
Backward trajectories ending at 1200 UTC 03 Jun 16

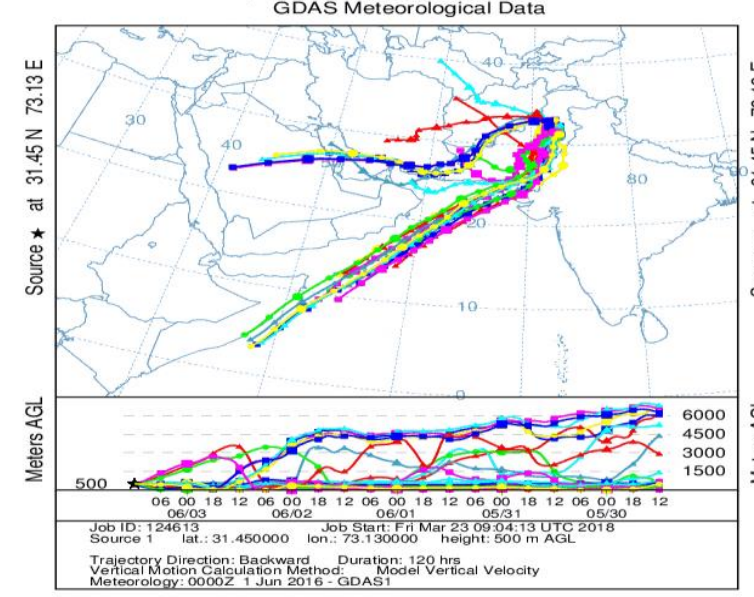

NOAA HYSPLIT MODEL

1200 UTC 02 Feb 16

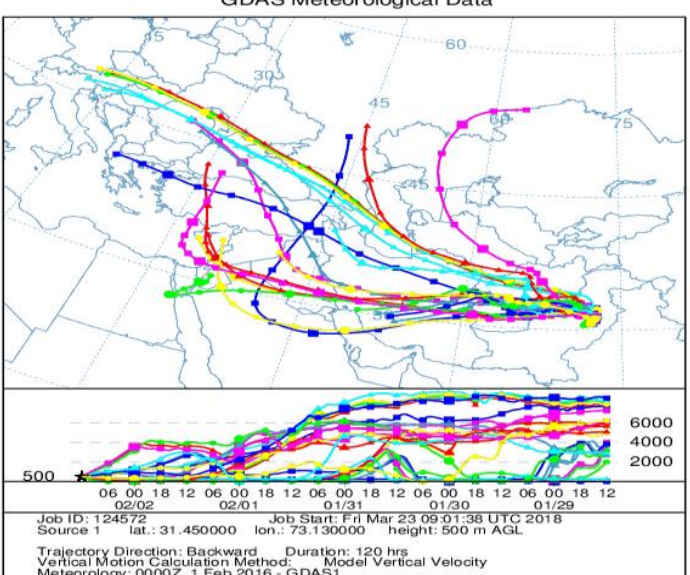

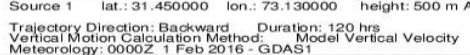

NOAA HYSPLIT MODEL
Backward trajectories ending at 1200 UTC 02 Aug 16

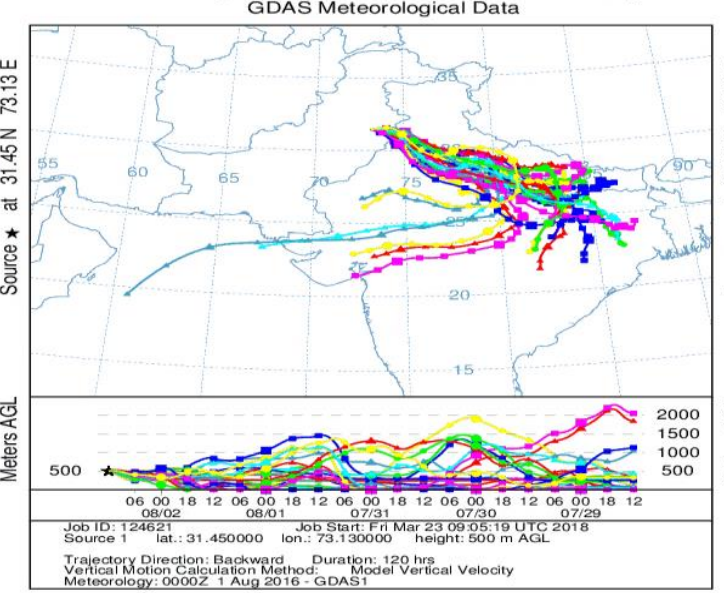

Backward trajectories ending at 1200 UTC 28 Mar 16

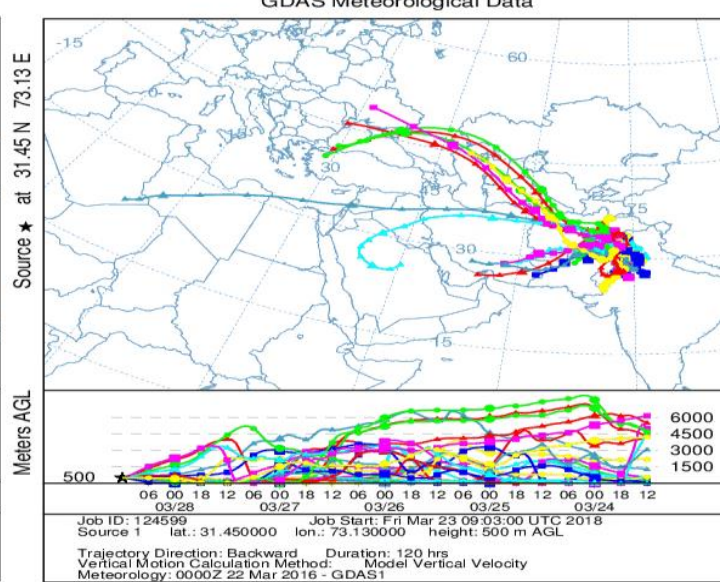

NOAA HYSPLIT MODEL
Backward trajectories ending at 1200 UTC 10 Nov 16

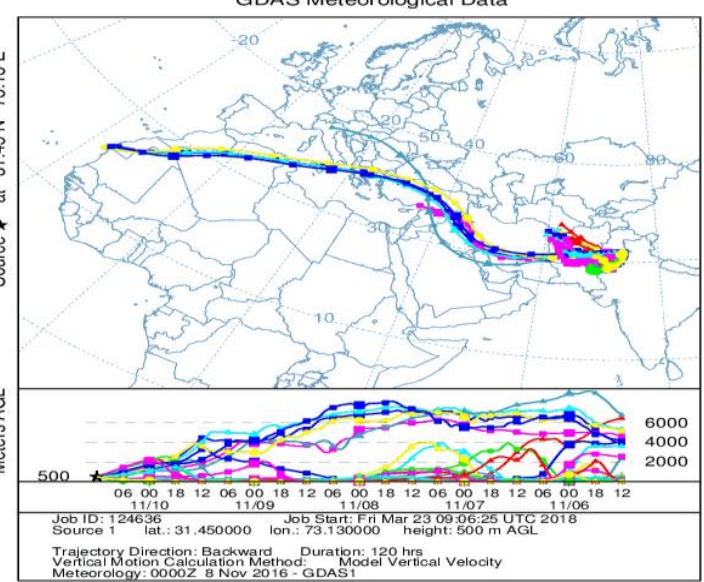

Fig. 1S. Three-days air mass back-trajectories simulate during different seasons at an altitude level of $500 \mathrm{~m}$ above ground level 